\title{
FEDERAL DEBT MANAGEMENT AND THE INSTITUTIONAL INVESTOR
}

\author{
Roger F. MurraX*
}

The magnitude of federal financial operations in the management of the public debt has made them a new but highly essential topic for consideration in appraising the principal factors affecting the institutional investor. As the interest-bearing debt of the United States Government reached 276 billion dollars at the end of 1945 compared with less than 48 billion dollars, at the end of 1939, debt management ceased to be largely an absorbing study for the money market technician. The size, composition, and distribution of this huge increase in the debt introduced to institutional investors a number of policy and operational questions for which only tentative answers have been found thus far.

\section{I}

\section{Objectives of Debt Management}

With the growth of the federal debt, certain basic objectives of debt management have emerged during recent years. Some of these objectives are of special significance to investing institutions.

\section{A. Low Interest Rates}

The direct and rather myopic objective of debt management has been to minimize the carrying charges on the public debt. Undoubtedly this will continue to be a cardinal purpose of Secretaries of the Treasury for many years to come. Problems of revenue raising are likely to resolve most doubts in favor of the course which keeps the interest rate as low as possible. It can be hoped, however, that this cost factor will be viewed in its proper perspective in relation to the many more pertinent considerations which are always present in reaching debt management decisions.

The idea that easy money is a panacea for many real and fancied ailments of the economy is, of course, an important foundation for policies directed toward maintaining rates at low levels. This is the objective which causes most concern to institutional investors, many of whom have contracted to pay fixed rates of return far into the future and all of whom are most eager to improve their investment income. Because easy money can be made to sound so attractive to so many people, savings institutions and individuals have a difficult task in effectively presenting the other side of the case. Yet such a presentation must be made repeatedly if the private thrift and eleemosynary institutions are to survive and prosper.

- B.A. 1932, Yale College; M.B.A. 1938, Ph.D. 1942, New York University, Graduate School of Business Administration. Vice President, Bankers Trust Company, New York, N. Y. Contributor to business and economic periodicals. The author is especially indebted to his colleagues, J. H. Riddle and Roy L. Reierson, for their assistance in the preparation of this article. The conclusions and opinions cxpressed are, of course, his own responsibility. 
There is little doubt about the ability of the authorities to maintain interest rates at comparatively low levels if they are prepared to ignore the other consequences of their actions. As has been demonstrated repeatedly, the maintenance of low rates in the face of conditions which would otherwise produce a firming in the rate structure will inevitably lead to either actual or potential inflationary pressures. There are times, of course, when the broadening of the credit base has no immediate consequences, and for the duration of such a period the authorities have, in effect, a free hand to apply a persistent pressure on rates. When inflationary tendencies are strong, however, easy money objectives are likely to come into sharp conflict with efforts to control the expansion of credit.

The search continues for some plan or device by which it would be possible to exercise restraint on the expansion of bank credit without raising interest rates on Government securities. Special reserve and loan reserve plans which are advanced from time to time reflect this effort to isolate interest rates from anti-inflation measures. The counterpart of the special reserve plan, which seeks to freeze Government securities in the commercial banking system, is the nonmarketable long-term bond made available to the institutional investor. These nonmarketable issues are designed to provide a penalty against redemption prior to maturity. Thus, we find a widespread variety of devices in operation and proposed for the purpose of maintaining low interest rates during periods when a rise would Iogically be expected.

\section{B. Accommodating Investors}

The maximum contribution can be made to an orderly market for Government securities by adapting new issues to the particular needs of different classes of investors. The Treasury has repeatedly stated as one of the cardinal purposes of debt management the provision of securities most appropriate to the requirements of the commercial banks, corporations, individuals, and savings institutions.

In part, this attitude simply recognizes the fact that it is always easiest to sell the types of securities in greatest demand. Attention to the preferences of different classes of investors also tends to assure more permanent placement of new issues. This has become of increasing importance as the size of the debt has impaired the ability of the open market to provide for the shiftability of large segments of the outstanding debt, particularly in the case of restricted bonds for which the commercial banking system cannot provide a market.

The existence of a very large volume of savings bonds of all series, redeemable at the discretion of the holders and largely maturing during the next few years, creates a special problem for the Treasury. A volume of redemptions fluctuating from time to time as conditions dictate is to be expected. Heavy encashments met by borrowing from the banks in a period of strong inflationary presssures would be undesirable, however, and make it difficult if not impossible to apply restrictive credit policies. It is especially important to place such demand obligations in the hands of those investors who are least likely to exercise the redemption privilege. This means 
making and keeping savings bonds attractive in comparison with other savings media.

A more important consideration, however, is that the debt should serve as a suitable medium of investment for many different requirements. The flexibility of the commercial banking system is certainly fostered by the availability of a very large volume of short-dated paper. In the case of savings institutions, longer-term securities are appropriate in part as permanent holdings for income, in part to provide for diversification of maturities, and over a period of years to permit a ready adaptation of investment portfolios to changing conditions in the capital markets. The latter function is performed most effectively by Government securities because they are acceptable assets to every type of institution or individual. We know that other types of assets, because of custom, law, or technical difficulties, cannot be as readily shifted from one holder to another, whereas every kind of investor can make some use of Government issues in his portfolio.

\section{Economic Stability}

Efforts to achieve a greater degree of stability in the economy are made on many fronts. The social security program, public works activities, agricultural price support schemes, tax legislation, and credit policy are among the many facets of the modern government's attempts to avoid booms and busts.

While it is generally admitted that there are important limitations to the contribution which credit policy can make to economic stability, it is only reasonable to expect that at least the actions of the authorities in this area will be in conformity rather than in conflict with other programs. Debt management can play a fairly important part in efforts either to restrain an inflationary boom or to check a persistent deflation. The sale of long-term bonds to individuals and savings institutions and the retirement of bank-held debt with the proceeds can be a restrictive force. The application of a budgetary surplus to the retirement of securities held by the Federal Reserve banks is an effective means of reducing the credit base. When the problem is largely one of deflation, deficit financing through the banking system will expand the money supply and a maximum easing of credit conditions can be quickly accomplished through the open market operations of the central bank.

In the past, contracyclical monetary policies have been thought of primarily as applying to the commercial banks: More recently, however, with the growing importance of savings institutions, it has become evident that their investing activities can have a very important effect upon the level of activity in heavy industry and all phases of construction. In the future, it seems logical to expect that debt management will be more directly related to developments in the long-term capital markets. Investing institutions must be prepared for this more active intervention in the markets which they dominate. 


\section{Dependence on Debt Management}

Because of the stability of the growth in savings as compared with the fluctuations which occur in the volume of private investment outlets, it is necessary to recognize the extent to which investing institutions have come to depend upon compensating operations in the management of the federal debt.

\section{A. Relative Stability of Institutionalized Savings}

It is well known, of course, that the flow of individual savings is relatively steady because of the importance of habit in regulating the affairs of individual family units. Even greater stability in the flow of funds is to be found in the principal savings institutions where habit is reinforced by promotion and salesmanship. In the case of life insurance, of course, the existence of a contract is an important factor because it provides for penalties in the event that payments are not made according to schedule.

The amounts flowing into savings institutions have reached a high level and it is important to observe the difference between such savings and those held by individuals at their own disposal. When a life insurance company, a mutual savings bank, or a savings and loan association gathers together the savings of a number of individuals it agrees to pay a certain rate of interest or dividend on these amounts.

\section{Chart I}

Selected Factors in the Supply of and Demand for Investament Funds

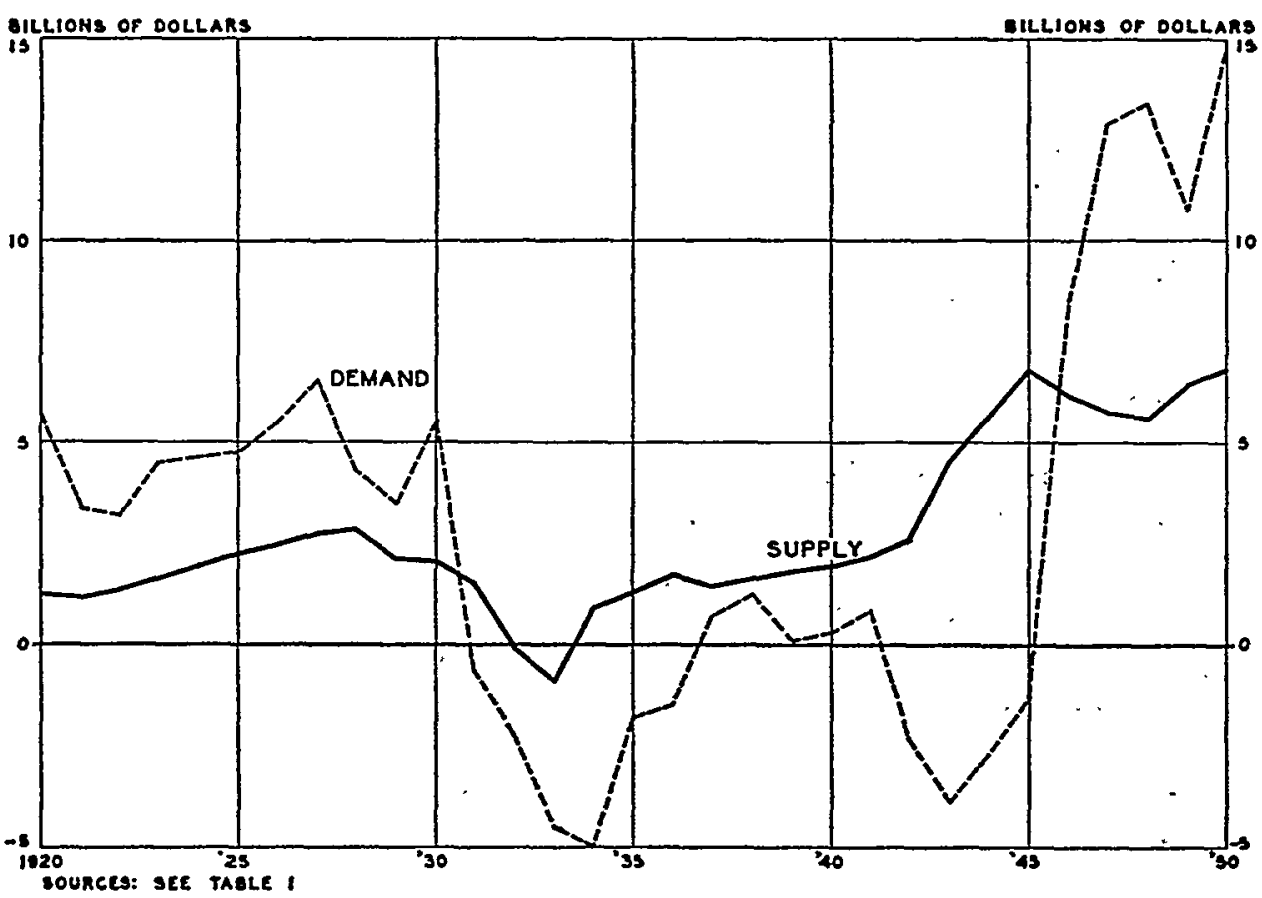


TABLE I

Selected Factors in the Supply of and Demand for Investment Funds, 1920-1950 (Amounts in Billions)

\begin{tabular}{|c|c|c|c|c|c|c|c|c|}
\hline \multirow[b]{2}{*}{ Year } & \multicolumn{4}{|c|}{ SUPPEX OF FUNDS ${ }^{1}$} & \multicolumn{4}{|c|}{ DeMaNd FOR Funds ${ }^{2}$} \\
\hline & $\begin{array}{c}\text { Life } \\
\text { Insurance } \\
\text { Cos. }\end{array}$ & $\begin{array}{c}\text { Mutual } \\
\text { Savings } \\
\text { Banks }\end{array}$ & $\begin{array}{c}\text { Savings \& } \\
\text { Loan } \\
\text { Ass'ns }\end{array}$ & Total & $\begin{array}{l}\text { Net Corp. } \\
\text { Long-Term } \\
\text { Debt }\end{array}$ & $\begin{array}{c}\text { Non- } \\
\text { corporate } \\
\text { Mortgages }\end{array}$ & $\begin{array}{l}\text { Net Debt } \\
\text { of State \& } \\
\text { Local Gov'ts }\end{array}$ & Total \\
\hline 1920. & $\$ 0.5$ & $\$ 0.4$ & $\$ 0.3$ & $\$ 1.2$ & $\$ 1.6$ & $\$ 3.4$ & $\$ 0.7$ & $\$ 5.7$ \\
\hline $1921 \ldots$ & 0.6 & 0.3 & 0.2 & 1.1 & 1.2 & (1.6 & 0.6 & 3.4 \\
\hline $1922 \ldots$ & 0.7 & 0.3 & 0.2 & 1.3 & 0.6 & 1.4 & 1.2 & 3.2 \\
\hline $1923 .$. & 0.8 & 0.4 & 0.4 & 1.6 & 1.8 & 2.2 & 0.5 & 4.5 \\
\hline $1924 .$. & 0.9 & 0.4 & 0.5 & 1.9 & 2.3 & 1.5 & 0.8 & 4.6 \\
\hline 1925. & 1.1 & 0.4 & 0.7 & 2.2 & 1.2 & 2.5 & 1.0 & 4.7 \\
\hline 1926. & 1.4 & 0.5 & 0.6 & 2.4 & 2.0 & 2.8 & 0.7 & 5.5 \\
\hline $1927 \ldots$ & 1.5 & 0.6 & 0.6 & 2.7 & 2.7 & 3.0 & 0.8 & 6.5 \\
\hline $1928 \ldots$ & 1.6 & 0.5 & 0.7 & 2.8 & 1.7 & 2.8 & 0.8 & 5.3 \\
\hline 1929. & 1.5 & 0.1 & 0.5 & 2.1 & 1.2 & 1.4 & 0.9 & 3.5 \\
\hline 1930. & 1.4 & 0.6 & 0.1 & 2.0 & 3.8 & 0.8 & 0.0 & 5.5 \\
\hline 1931. & 1.3 & 0.6 & -0.4 & 1.5 & -0.8 & -1.3 & 1.4 & -0.7 \\
\hline 1932. & 0.6 & -0.1 & -0.6 & -0.1 & -1.1 & -2.2 & 1.1 & -2.2 \\
\hline 1933. & 0.1 & -0.4 & -0.6 & -0.9 & -1.3 & -3.3 & 0.1 & -4.5 \\
\hline 1934. & 0.9 & 0.3 & -0.3 & 0.9 & -3.3 & -0.9 & -0.8 & -5.0 \\
\hline $1935 .$. & 1.4 & 0.1 & -0.2 & 1.3 & -1.0 & -0.9 & 0.1 & -1.8 \\
\hline 1936. & 1.7 & 0.2 & -0.1 & 1.7 & -1.1 & -0.6 & 0.2 & -1.5 \\
\hline 1937.. & 1.4 & 0.1 & $-0 . \overline{1}$ & 1.4 & 1.0 & -0.2 & -0.1 & 0.7 \\
\hline 1938. & 1.5 & $0 . \overline{1}$ & 0.0 & 1.6 & 1.3 & 0.0 & $-0 . \overline{1}$ & 1.2 \\
\hline 1939. & 1.5 & 0.2 & 0.1 & 1.8 & -0.4 & 0.2 & 0.3 & 0.1 \\
\hline $1940 \ldots$ & 1.6 & 0.1 & 0.2 & 1.9 & -0.7 & 0.8 & 0.2 & 0.3 \\
\hline 1941.. & 1.9 & -0.1 & 0.4 & 2.2 & -0.1 & 1.1 & -0.2 & 0.8 \\
\hline 1942. & 2.2 & 0.1 & 0.3 & 2.6 & -0.9 & -0.9 & -0.5 & -2.3 \\
\hline 1943. & 2.8 & 1.1 & 0.6 & 4.5 & -1.7 & -1.3 & -0.9 & -3.0 \\
\hline $1944 \ldots$ & 3.3 & 1.6 & 0.8 & 5.7 & -1.2 & -0.7 & -0.8 & -2.7 \\
\hline $1945 \ldots$ & 3.7 & 2.0 & 1.1 & 6.8 & -1.5 & 0.7 & -0.4 & -1.2 \\
\hline 1946. & 3.4 & 1.5 & 1.2 & 6.1 & 3.0 & 5.8 & $-0 . \overline{2}$ & 8.6 \\
\hline 1947. & 3.6 & 0.9 & 1.2 & 5.7 & 4.8 & 6.6 & 1.6 & 13.0 \\
\hline $1948 \ldots$ & 3.8 & 0.6 & 1.2 & 5.6 & 6.4 & 6.7 & 2.0 & 15.1 \\
\hline $1949 \ldots$ & 4.1 & 0.9 & 1.5 & 6.5 & 2.9 & 5.6 & 2.1 & 10.6 \\
\hline $1950 .$. & 4.4 & 0.7 & 1.6 & 6.7 & 2.8 & 9.6 & 2.3 & 14.7 \\
\hline
\end{tabular}

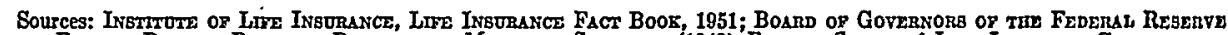

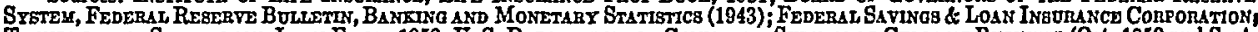

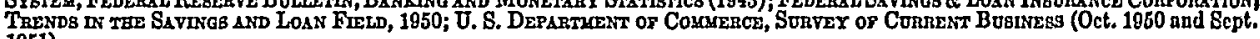
1951).

IN Fet increase or decrease in assets available for investment. Components will not necessarily add to totals becauso of rounding. 2 Net increase or decrease in corporate long-term debt excludes intercorporate debt but includes mortgages and term loans of commercial banks. Changes in the net debt of state and local governments are for fiseal years ending June 30 . Components rill not neccssarily add to totals because of rounding.

They must be invested, therefore, and start earning some return immediately. The same funds added to a demand deposit account or stored under the traditional mattress involve no commitment for a rate of return. A high and relatively stable level of institutional savings, therefore, creates a rather inflexible factor in the capital markets. This contrasts, of course, with the substantial range of fluctuations which normally occur in the demand for permanent capital.

The general nature of these relationships is shown in Chart I-"Selected Factors in the Supply of and Demand for Investment Funds." The data used are shown in Table $r$. The purpose of this chart is simply to illustrate the characteristic stability 
of the yearly supply of funds in a selected group of savings institutions (life insurance companies, savings and loan associations, and mutual savings banks) compared with the annual demand as represented in part by changes in net corporate long-term debt, in noncorporate mortgages, and in the net debt of state and local governments. These are, of course, net figures for both supply and demand. The new investments made each year substantially exceed the net additions to assets because of repayments. In the case of life insurance companies, for example, new loans and investments have typically exceeded new funds by $5^{\circ}$ per cent and more.

The long period of the r920's, the middle and late 1930's, and the late 1940's set general levels for the rate of growth in these savings institutions which were reasonably predictable from year to year. Since these institutions were practically prohibited by law from investing in equity securities, the comparison is made with changes in selected forms of long-term debt without reference to new equity money sought in the capital markets. The picture presented here is restricted, therefore, to the area in which debt management operates: the field of bond and real estate mortgage investments.

Of growing importance, especially in recent years, are the accumulations of funds in trusteed pension funds. There are at present no adequate statistics on the volume of funds available for investment each year from this source. Estimates made by Bankers Trust Company, New York, indicated that by the beginning of 195I the rate of growth in trusteed pension funds approximated I billion dollars. Chart I does not reflect this addition to the supply of funds, but it can be visualized as a layer of gradually increasing width. It is another element of stability because in the main pension fund contributions show only moderate variations from year to year.

No comprehensive information has yet been gathered on how these funds are being invested, although it is evident that corporate bonds represent the largest single outlet for funds. Because it is not possible to trace the shifts which have occurred in pension fund holdings, they have been omitted from the discussion which follows. Pension funds have become a significant factor in the capital markets, but for the present purposes they must be treated simply as a component of the general category of institutional funds, along with endowment funds and other large aggregations of capital invested on a long-term basis.

For most years it would also be appropriate to add changes in time deposits of commercial banks to the supply of investment funds, but it has seemed preferable to exclude these amounts because of the distortions which occurred during the period of bank failures and the fact that it is virtually impossible to distinguish the corresponding assets in commercial bank portfolios. If the change in time deposits were included, it would have the effect of widening the range of fluctuations in the supply of funds shown in Chart $I$. The figures for changes in time deposits are given in Table 2 for convenient reference. 
The activities of insured commercial banks relevant to this discussion were as follows during the period from December 3I, I945 through December 31, x950:

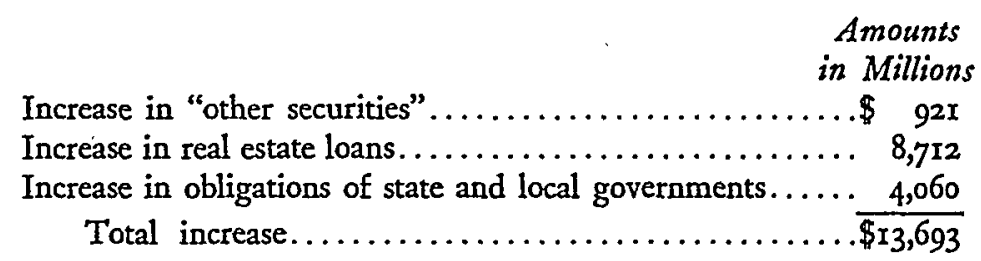

This compares with a time deposit increase of 6.2 billion dollars for this group of banks, giving an indication of the extent to which bank credit was used in meeting the demand for funds in these areas.

\section{TABLE 2}

Growth in Time Deposits* of Commerctai. Banks, I920-I950 (Amounts in Billions)

$\begin{array}{lccc}\text { Year } & \text { Increase } & \text { Year } & \text { Increase } \\ 1920 & \$ 1.0 & 1937 & \$ 0.7 \\ 1921 & 0.6 & 1938 & 0.0 \\ 1922 & 0.9 & 1939 & 0.5 \\ 1923 & 1.7 & 1940 & 0.5 \\ 1924 & 1.4 & 194 \mathrm{I} & 0.1 \\ 1925 & 1.3 & 1942 & 0.5 \\ 1926 & 0.9 & 1943 & 2.9 \\ 1927 & 1.5 & 1944 & 4.9 \\ 1928 & 0.8 & 1945 & 6.1 \\ 1929 & -0.6 & 1946 & 3.7 \\ 1930 & -0.2 & 1947 & 1.4 \\ 1931 & -3.6 & 1948 & 0.6 \\ 1932 & -1.7 & 1949 & 0.3 \\ 1933 & -2.6 & 1950 & 0.2 \\ 1934 & x .2 & & \\ 1935 & 1.0 & & \\ 1936 & 0.9 & & \end{array}$

* Excluding interbank time deposits and postal savings redeposited in banks.

Source: Board of Governors of the Federal Reserve System, Banking and Monetary Statistics (1943), Federal Reserve Bullettin.

In the 1930's, when the demand for funds was low relative to savings, it is interesting to observe how insured commercial banks had the reverse experience. From December 3I, I934 to December 3I, 1939, time deposits increased by 3,045 million dollars, but the net increase in the same groups of assets was much less.

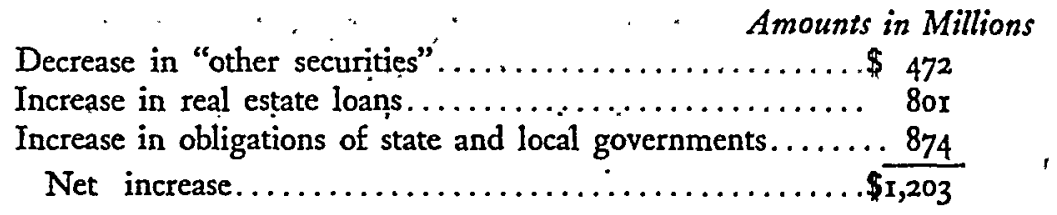


It can be observed in passing, therefore, that the commercial banks provide a flexible factor in equating the supply of and the demand for investment funds. The extent of their participation, however, will depend in part upon the policies of ease or restraint followed by the Treasury and the Federal Reserve.

\section{B. Methods of Equilibrating Supply and Demand}

It might be argued that the achievement of an equilibrium between the supply of and demand for long-term capital is the proper function of the rate of interest. Undoubtedly over a long period of years interest rates can be an important factor. Realistically, however, we know that life insurance, for example, is sold by salesmen and not bought by savers. The cost of the insurance, as affected by the rate of interest among other factors, has some influence, but we know from long experience that direct selling is the principal reason for the rapidity of the growth in life insurance company assets. During the last 20 years, during which the interest rate earned by life insurance companies declined by almost 40 per cent and many of the costs of doing business rose substantially, the full effects of these developments were obscured by the continuing improvement in mortality experience. The cost of life insurance did not rise to the extent suggested by the decline in interest rates, with the result that the flow of savings to these institutions was not curtailed on that account.

As promotion and salesmanship continue to strengthen the already deeply ingrained habits of channeling savings through the principal investing institutions, it seems probable that only such drastic developments as a deep depression or a sustained inflationary buying spree are likely to influence materially the rate of accumulation of funds for them to invest. There is no such assurance, however, of comparable stability in the demand for long-term capital. In spite of all the studies of the causes of changes in capital expenditure programs, there is little convincing evidence that we have learned how, in a dynamic free society, to eliminate the greater portion of the year-to-year variations which have been typical of our experience over many decades.

One possible method of achieving a limited elasticity in the supply of funds for the capital markets would be to establish a kind of central bank or investment bank for the various institutions. This approach is exemplified by the Federal Home Loan Banks in the discount privileges which they afford savings and loan associations for home mortgages. In the residential housing boom following World War II, the accumulation of savings in these institutions did not keep pace with the volume of suitable mortgage loans. Through the functioning of the Federal Home Loan Banks, member associations were able to supplement their own resources by more than 600 million dollars to help meet the very active demand for funds.

In the early postwar years, a central institution might have functioned to supplement the ability of the life insurance companies and other savings funds to meet the rapid increase in corporate long-term borrowing. The institution would have 
found it necessary, however, either to sell short-term securities to the commercial banks or to borrow from them. In the United States, it seems very doubtful that such an investment bank would provide a desirable method of providing elasticity to the capital markets. The principal danger is that the institution would always operate to expand the supply of funds but never to contract it. Experience shows that agencies designed to finance soon become agencies to promote. It appears that only an institution having the broadest responsibilities for economic stability can be expected to have the courage to restrain a boom before excesses result.

It seems far preferable to rely on the financial agencies which now exist and effectuate their purposes by transactions in Government securities. They can influence market prices, change the maturities of the debt as between long-term and short-term, alter the composition as between marketable and nonmarketable issues, and facilitate the shifting of securities from one group of holders to another. Sales, purchases, and refundings are the methods by which the Treasury and the Federal Reserve System operate, but the state of the federal budget is also an important factor.

The function of budget surpluses was illustrated in its simplest form during the years I9zI through $193^{\circ}$ when debt was being regularly retired. In this period of relatively high demand for permanent debt capital on the part of industry, the life insurance companies and mutual savings banks sold or redeemed close to 700 million dollars of their Government securities, representing over $4^{\circ}$ per cent of what they held in I920. In the years I934 through 1939, on the other hand, Government deficits, financed in part through the savings institutions, were reflected in a 6.9 billion dollar expansion in the Government securities held by these two groups. This represented an increase of $43^{\circ}$ per cent during the years of low capital demands from private sources.

The problem is obviously not as simple as this partial record of the past might seem to indicate. A great many factors, entirely apart from debt management objectives, will be responsible for the budget position and no real flexibility has been achieved in this area. The authorities must be prepared, therefore, to take appropriate action whether or not they would have the active assistance of the desired budget situation.

\section{Portfolio Policies after World War II}

After the close of World War II, the principal investing institutions had a new interest in the debt management questions facing the Treasury and Federal Reserve authorities by reason of their greatly expanded holdings. For example, life insurance companies at the end of 1945 owned 20.6 billion dollars of Government securities compared with 5.4 billion dollars at the end of 1939. Mutual savings banks increased their holdings from 3.I billion dollars to I0.7 billion dollars during the same period. These and other institutional holdings were, of course, largely concentrated in the $2 \frac{1}{2}$ per cent long-term bonds not eligible for commercial bank investment. 
The market behavior of the restricted bonds became of interest because of the limited supply of bonds. Of great importance, however, was the prevalence of premiums in the market, which assured holders of the ability to shift into other forms of investment at any time without penalty and, in fact, with a profit for all original subscriptions at par. Thus, savings institutions enjoyed the most liquid position in their history, feeling secure in the belief that their Government securities would always command a price of par or better.

This frame of mind was the product of the policies followed in the months after the termination of hostilities. The Treasury used its excessively large cash balance accumulated from the Victory Loan drive to retire maturing notes and certificates of indebtedness held by the banking system and by nonfinancial corporations. The aggregate reduction in marketable securities during the year 1946 exceeded 22 billion dollars and further retirements were in prospect. Therefore, there was no apparent need or inclination to issue long-term marketable bonds which might depress the prices of outstanding issues.

Most effective in strengthening confidence in the maintenance of the $2 \frac{1}{2}$ per cent rate were the repeated assurances given by Treasury and Federal Reserve officials. The Treasury consistently argued that breaking through par on the long-term $2 \frac{1}{2}$ per cent bonds would seriously interfere with its large refunding operations, might induce larger encashments of savings bonds, and even cause loss of confidence in the Government's credit. Furthermore, there was no weakening in the devotion to easy money as a permanent policy not only in order to keep down the carrying cost of the debt but also because of its alleged benefits to the economy. In the elaborate program to stimulate residential housing, for example, the prevalence of low money rates for decades to come was regarded as essential.

Even when the rising clamor for an unfreezing of short-term interest rates reached a crescendo in the winter of I946-I947 as inflationary pressures became evident, it was repeatedly stated that no change was contemplated in the $2 \frac{1}{2}$ per cent long-term rate. It appeared, therefore, that nothing could impair the liquidity of the restricted bonds held by institutional investors. That being the widely shared assumption, there was no reason to own short-term securities which provided very low rates of return. Why should an institutional investor, without either demand deposits or other short-term liabilities, hold Government securities maturing in less than ten years?

Debt management as practiced during 1946 and early I947, together with assurances given for the indefinite future, had the effect, therefore, of inducing institutional holders of Government securities to succumb to the strong appeal of a desperately needed higher yield. Since requirements for liquidity were assumed to be satisfied by the assurances of the monetary authorities, institutional investors became dependent upon debt management policies. It was easy for the portfolio manager to forget that he had exchanged the freedom and independence of short 
maturities for the better paid but less certain position of the hopeful beneficiary of a protected, supported market for long-term bonds. Thus the events and policies of the war and immediate postwar years gave institutional investors an unprecedented concern with federal debt management policies.

\section{III}

\section{Providing Flexibility to the Capital Markets}

The most effective way of examining the possibilities and problems of contributing to economic stability through adding a limited elasticity to the supply of investment funds is to review briefly the two important postwar operations: the pegs of 1947I948 and the removal of the pegs in I95I.

\section{A. The Pegs of $1947^{-1948}$}

Inflationary pressures continued strong into 1947 after a brief pause early in the year. Finally and reluctantly the Treasury agreed to permit the rate for 9r-day discount bills to rise in July and took the first step to free the rate on one-year certificates of indebtedness in refunding the August maturity. This firming of short-term rates was in contrast to the behavior of long-term issues. From April through September, sales of bonds from various Treasury and agency investment accounts totaled I.8 billion dollars as part of the effort to keep prices from rising. Since the Federal Reserve banks held less than 800 million dollars of bonds, they could not add appreciably to the supply.

Late in September, in response to the repeated urgings of institutional investors, the offering of almost I billion dollars of $2 \frac{1}{2}$ per cent Investment Series A bonds redeemable at a fixed scale of discounts prior to a 1965 maturity rather thoroughly completed the job of supplying the market. From the vantage point of hindsight, it is clear that the Investment Series A bonds were not needed at all. Almost immediately after their October I issuance date, there occurred a very substantial increase in the volume of new corporate financing at somewhat higher rates; the demand for mortgage money rose further; and state and local governments were borrowing actively. At the same time, the rate of increase in savings flattened out in some institutions and declined in others. The fourth quarter of 1947 showed a radically altered situation.

By November the Treasury investment accounts and the Federal Reserve banks had become substantial buyers in their reluctant support of a declining bond market. Lack of confidence in the support policy, partly induced by the rise in short-term rates, soon became widespread in spite of assurances that par would not be violated. On December 24, 1947, it became necessary for the Federal Reserve to state that they would take all offerings at a fixed price. This peg was set at $1001 / 4$ for the Victory $21 / 2$ per cent bonds of $1967-72$, representing a decline of almost 3 points from prices prevailing during the first half of the year. The first week of this fixed support operation resulted in Federal Reserve purchases approximating I billion dollars. This selling continued into the early months of 1948 at a very high rate. 
Selling by institutional and other holders gradually dried up and the long-term restricted bonds moved above the pegs during May. In July, however, the Treasury made a special offering of Series $F$ and $G$ savings bonds, for which subscriptions exceeded I billion dollars. At about the same time, action taken to restrict bank credit expansion and to stiffen short-term rates revived nervous liquidation of the pegged long-term bonds. This continued rather persistently until early November. By that time, the levelling off in commodity prices, bank loans, and new capital expenditures indicated the subsiding of inflationary pressures. The outcome of the presidential election served to strengthen confidence in the support policy and institutional selling subsided. This pegging operation was completed.

In attempting to appraise the support operation, it seems appropriate to ask at least three questions:

(x) Did it make a worthwhile contribution to economic stability through its effects in the capital markets?

(2) Were there other collateral effects which were undesirable for or damaging to other sectors of the economy?

(3) Could it have been more effectively executed?

In attempting to answer the first question, it is important to observe how various institutional investors used the funds made available to them by the bond support operation. In round numbers, the life insurance companies on balance sold or redeemed United States Government securities amounting to almost 5 billion dollars during the years 1947 and 1948 . As a consequence they were able to increase their mortgage loans and their holdings of corporate securities by some II billion dollars, when actual growth in resources only slightly exceeded $\eta$ billion dollars for the two years. In effect, therefore, the pegging of long-term bonds facilitated a substantial contribution by these institutions to the financing of the postwar capital expenditure and housing booms. The liquidation of Government securities by mutual savings banks and by savings and loan associations exceeded $\mathrm{I}$ billion dollars during these same two years. This, of course, also permitted mortgage lending and corporate bond investing in amounts exceeding the actual growth in savings.

Whether this method of expanding the lending and investing capacity of the savings institutions contributed importantly to the inflation is a moot point. The short-run impact of the capital expenditures which were financed in amounts greater than otherwise would have been possible undoubtedly contributed to the upward pressure on prices. However, it is difficult to distinguish this influence from many other inflationary forces such as wage policies, buying agricultural commodities for export, the support of farm prices, and the activation by both business and consumers of the tremendous liquid assets created during the war. The huge expenditure programs for electric power, communications, petroleum production, and increasing the productive capacity of industry generally also had the longer run effect of in- 
creasing efficiency, expanding the supply of goods, and easing the upward pressure on prices. In this respect it seems clear that the heavy capital expenditures of 1947 and 1948 made a very substantial contribution to the complete subsiding of inflationary pressures by the middle of I949. In terms of the objective of contributing to economic stability, therefore, a reasonably good case can be made for the desirability of the bond price support program.

In the process, furthermore, certain other objectives of debt management were achieved. Disorder in the Government securities market was avoided and no serious problems were created for the Treasury in its periodic refunding operations. By making long-term Government bonds liquid and shiftable between individuals and institutions, the desirable function of the public debt in providing liquidity and flexbility to the capital markets was effectively served.

It has frequently been argued, however, that the program produced collateral effects which were undesirable, especially during late 1947 and early 1948 when inflationary pressures were still strong. The basis of this criticism is primarily that every purchase of bonds from the savings institutions by the Federal Reserve banks added a corresponding amount to member bank reserves, the greater part of which were available as the basis for a multiple expansion of bank credit. The validity of this argument depends, of course, upon the assumption that the commercial banks would use these reserves to extend credit, not for expanding production or expediting the distribution of goods and services, but for speculating in inventories, keeping goods off the market, and generally increasing the money supply more rapidly than the rate of growth in the availability of goods and services.

What actually happened was that during the period of support operations from November 5, 1947 to November 3, 1948, the Federal Reserve banks increased their holdings of bonds by ro.4 billion dollars but during the same period they had net sales and retirements of discount bills, certificates of indebtedness, and notes aggregating 9.3 billion dollars. The net contribution to the credit base was not substantial, therefore, and as a matter of fact the money supply of the country declined by nearly 2 billion dollars in $194^{8}$ as commercial banks and other lending institutions displayed great caution and followed conservative policies in their operations. Considering the basic strength of inflationary pressures during these years, it is really remarkable that there was so little speculation in commodities and inventories. On the whole, therefore, it does not appear that any substantial portion of the benefits of the bond support operation was offset by damaging consequences to other sectors of the economy.

The outcome was very greatly influenced by the favorable budgetary situation which existed during 1948. For that calendar year the Treasury showed a cash surplus on all accounts amounting to 8.I billion dollars. The debt retirement which this permitted accounts for the very moderate expansionary consequences of the bond support operations. This illustrates, of course, how the execution of debt 
management policies are influenced by the federal position as to revenues and expenditures, which may either provide ammunition for debt management or exercise limitations on its effectiveness.

Any finding as to whether the support program could have been more effectively executed must obviously be in the affirmative because of the overwhelming superiority of hindsight over foresight in such matters. On the whole, it must be conceded that the program was a success. The expansion in productive capacity was facilitated while the inflation was beginning to subside. The mildness of the recession in 1949 and the prompt appearance of signs of recovery from that episode constitute convincing evidence that excesses were avoided.

In retrospect, however, it does seem that several policy decisions might have been made differently. The sale of the Investment Series A bonds in September 1947 was urged by investors and agreed to reluctantly by the Treasury. By mopping up available funds, it added to the size of the support operation almost immediately. No one fully anticipated the magnitude of the expansion in new corporate and mortgage financing which lay ahead. The special offering of Series $F$ and $G$ savings bonds in July 1948 made the last phase of the support program more difficult. The timing of these offerings was certainly unfortunate.

A more controversial question is whether, when a fixed peg was found necessary, a mistake was not made in setting it above par for the Victory $2 \frac{1}{2}$ per cent bonds of rg67-72. In this case it appears that the fetish of par interfered with the proper execution of a program. Support at this level meant, in effect, that very little restraint was being placed on selling by institutional investors. Setting the support point at a discount of even a point or two would have had the desirable effect of acting as a modest drag on the capital expenditure boom. Such an application of brakes would be entirely in keeping with the established principle that, in a period of boom, debt management and other policies should restrain the expansion of loans and investments.

The use of a support point of par or above for the long-term restricted bonds also served to reinforce the notion of institutional investors that they could always obtain at least par for their holdings. How greatly this belief was strengthened is evidenced by the fact that the life insurance companies and mutual savings banks simply sold long-term bonds to meet their other requirements. They did not take the further step of selling long-term bonds and acquiring short-term securities to cover the further expansion in mortgages and corporate bonds which lay ahead. This, of course, had very important implications under the circumstances which developed in $1950-1951$.

\section{B. Removing the Pegs}

During the first half of I949, the bond portfolios of the Federal Reserve banks were reduced by more than 3 billion dollars as the rising trend of bond prices was kept in check by open-market sales. At mid-year, however, the restrictive effect 
of such sales on bank reserves was recognized and it was decided to cease selling bonds, permitting prices to rise by two points and more for the long-term restricted bonds. This was part of a general relaxation of controls because the business picture was dominated by inventory liquidation and declining capital expenditures.

In the early months of 1950, however, business activity and prices moved upward and it was thought best for the Federal Reserve banks to sell long-term bonds in the open market in order to reduce the existing premiums and to effect a gradual pressure on bank reserves. In the months of October, November, and December, the books for Series $F$ and $G$ savings bonds were opened for short periods to institutional investors. Total subscriptions during this period exceeded 900 million dollars.

By the fourth quarter of 1950 , the selling of long-term Governments by life insurance companies and savings banks to meet commitments became substantial. Because of the inflationary forces generated by the Korean war, support of the market was not desirable from the standpoint of credit policy. Purchases of bonds by the Federal Reserve added to member bank reserves at a time when bank loans were expanding at an unprecedented rate and some tightening in the money market seemed appropriate. The situation was quite different from that which prevailed in $194^{8}$ when inflationary pressures were subsiding and a substantial Treasury surplus permitted partially offsetting retirements of short-term issues. During the latter months of 1950 , it was not possible to neutralize the expansionary effects of supporting the market for restricted issues. Nevertheless, between September 6 and the end of November, the Federal Reserve bought over 700 million dollars of longterm bonds. In these and subsequent support operations, a price of $10022 / 3^{2}$ gradually became established as the new peg.

During this period, there was, of course, widespread discussion of credit policy, with emphasis on the difficulties of restraining credit expansion while the Federal Reserve was still obligated to support Government securities at fixed prices. The emphasis placed by the Federal Reserve on the need for flexibility in long-term as well as short-term interest rates was offset by reassurances from Secretary of the Treasury Snyder as late as January I8 as to the inviolableness of par for the longterm restricted bonds. Selling continued, however, as institutional investors made provision to take up commitments, especially for real estate mortgages.

On March 4, 195r, the "accord" between the Treasury and the Federal Reserve was announced. With this meeting of the minds on at least several major aspects of credit policy came the unveiling of a brand new exhibit in the display of debt management devices. This was the $23 / 4$ per cent nonmarketable bond dated April $\mathrm{x}$, I951, due April I, I980, and callable April I, I975. Offered in exchange for the longest restricted $21 / 2$ per cent bonds due June 15 and December 15 , $1967-72$ outstanding in the amount of almost 20 billion dollars, the new bond was made nonredeemable but exchangeable at any time for five-year $\mathrm{I}^{1 / 2} \mathrm{z}$ per cent marketable Treasury notes. 
Three days of continued pegging the $2 \frac{1}{2}$ per cent bonds of $1967-72$ at the roo 22/32 price brought forth large offerings and by March 8 fixed support was withdrawn. After April 6 when the books were closed on the conversion offer (accepted by private holders of almost 8 billion dollars of bonds, in addition to $5^{1 / 2}$ billion dollars of Treasury and Federal Reserve holdings), the decline in prices continued until mid-May, when discounts of around three points prevailed for the long-term restricted bonds. At this level, selling eventually dried up. Influential in this result was the participation of the principal savings institutions in the Voluntary Credit Restraint Program, which discouraged making certain types of new loans and commitments. Moral suasion against selling additional bonds was effectively coupled with the realization that it was very difficult to find buyers for bonds in any substantial volume.

The removal of fixed support prices was, of course, a real shock to those investing institutions which had wholeheartedly subscribed to the belief that their long-term bonds could fluctuate only in the area above par. It was especially discomfiting to those who held the long bonds as their provision for near-term mortgage commitments. Nevertheless, no drastic consequences eventuated. Paper profits gave way to paper and even realized losses; but institutional investors as a group were well protected by surpluses accumulated during the long period of rising bond prices.

An evaluation of the removal of the pegs can be made in terms of the same three questions which were raised regarding the pegging operation of 1947-1948. Any answers must be tentative and preliminary, because of the short time which has elapsed. However, some general conclusions can be reached on the principal features of the dramatic events of March and April $195 \mathrm{I}$.

In $x 948$, when the inflationary pressures were subsiding, it was reasonable to encourage the expansion of productive capacity and housing. In I950-I95I, however, recurring shortages were in prospect and steps were being taken to restrict all except defense and defense-supporting capital outlays. It was definitely appropriate to apply the brakes to the lending and investing of the savings institutions. The decline in the prices of long-term Government bonds was certainly one of the ways in which it was possible to make more effective other measures such as Regulation X, applying to real estate credit, and the Voluntary Credit Restraint Program.

It will not be possible to determine precisely how much was accomplished by making Government bonds liquid only at a penalty rate, but it seems safe to say that the effect on the mortgage market was substantial and that corporate and municipal borrowing was at least moderately curtailed. In relation to the rather modest objectives of debt management, this would seem to make the operation a success in its application to the capital markets.

The collateral effects, far from being damaging, were on the whole highly salutary. The removal of fixed support prices permitted greater freedom and flexibility in executing moderately restrictive credit policies. While it is true that there are very 
real limitations on what can be accomplished through modest changes in interest rates, it must be recognized that in dealing with a basically inflationary situation it is desirable to use every weapon at our command. Just because credit policy cannot be counted among the most incisive weapons, we should not let it rust and grow dull from disuse.

Again, with the benefit of the better perspective provided by hindsight, we may be able to point to ways in which the unpegging operation could have been more effectively executed. We may conclude that it was unnecesarily abrupt because of the lack of advance agreement as to how it should be accomplished. It can also be argued rather convincingly that the event was three to six months overdue. However, taking into account all of the circumstances prevailing at the time and the problems which they presented, perhaps a salutation of "well donel" was fairly earned.

\section{A New Type of Security Appears}

The removal of the pegs was marked by a special event of importance for the future: the conversion offering of $2^{3 / 4}$ per cent bonds of April $x$, x975-80 which are exchangeable into five-year $x 1 / 2$ per cent notes at the option of the holder. More than 13 billion dollars of these bonds were issued and almost 8 billion dollars of them were placed privately, largely in the hands of institutional investors. Was this the creation of a new, promising type of instrument for debt management or was it a stillbirth resulting from the breeding of incompatible purposes, conceived in desperation and delivered in confusion?

Institutional investors are vitally concerned with the question because the widespread use of this type of security would require major revisions in their portfolio management policies. Also, these investors should be wary of the strong predilection of the Treasury for nonmarketable bonds. Between the end of 1945 and the middle of 195 I the proportion which marketable issues represented of the total publicly held interest-bearing debt declined from 78 per cent to less than 63 per cent. The amount of the reduction in marketable securities was almost $6 \mathrm{r}$ billion dolars.

The defense for this type of security is based in part on the view that too large amounts of marketable bonds were insecurely placed in the hands of the savings institutions during World War II. In an effort to correct this mistake, the argument runs, any kind of a nonmarketable issue was desirable which would reduce the volume of weakly held bonds. At a time when the outlook for long-term rates was uncertain, it was necessary to include the escape provision through the $I \frac{1}{2}$ per cent note in order to obtain a fair volume of exchanges.

The preference for nonmarketable offerings is based in large part on the assumption that they "lock up" bonds and thus reduce the size of the problem in whatever debt management situations may arise. The validity of this assumption is open to serious question, especially in the case of savings bonds and notes or issues such as the Investment Series A bonds which have fixed redemption schedules. Flexi- 
bility is lost because the redemption values are irrevocably fixed at the time of original issuance. The monetary authorities give up the influence which they can exercise over marketable bonds through open market operations.

The new $23 / 4$ per cent bonds were designed, of course, to meet the difficulties for debt management of the fixed redemption schedule. By influencing the interest rate applicable to five-year maturities, the authorities can presumably cause the $I 1 / 2$ per cent notes to sell at discounts to discourage redemptions in periods of boom. On the other hand, in a period of persistent deflation the notes might be permitted to sell at par or even at a premium in order to encourage the holders to shift into loans and investments which would facilitate private capital expenditures.

Unfortunately for this purpose, the range of fluctuations in price possible for a five-year note, assuming only moderate changes in the general pattern of interest rates, does not seem sufficient to serve the purpose. A yield range from $\mathrm{I}^{1 / 4} \mathrm{per}$ cent to $2 \frac{1}{2}$ per cent involves a change in price from $101^{1} 1 / 4$ to $953 / 8$, or less than 6 points. A

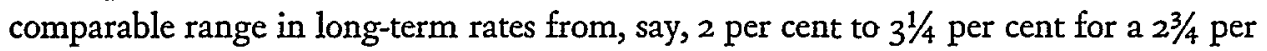
cent bond maturing in thirty years and callable in twenty-five would be over 24 points, from $I_{4} 3 / 4$ to $90 \frac{1}{2}$. There can be no disputing the limited usefulness of the five-year note, therefore, as a medium for influencing liquidation in comparison with the influence which could be exercised on holders of long-term marketable bonds.

The other obvious disability of the new $2^{3 / 4}$ per cent bonds from the standpoint of debt management is that the holders at their option can exchange a security ineligible for commercial bank investment for an eligible one whenever they choose. This means that the authorities to this extent have given up their control over the supply of commercial bank investments. This would be particularly significant if the same kind of a conversion offering were successfully made for a large portion of the restricted bonds now outstanding.

No one can tell now, of course, how the new bonds will serve their purpose. That will depend upon what develops during the next twenty-four to twenty-nine years. One is justified in taking the view, however, that there has been no new discovery in the technique of debt management which will solve all of the problems likely to arise. On the contrary, it seems fair to conclude that debt management may have been further complicated without actually promising any real assistance. If this proves to be the case, the verdict on the $23 / 4$ per cent conversion bonds of $1975^{-}-80$ will have to read that it was hardly worth the try.

IV

IMPLICATIONS FOR THE FUTURE

The preceding discussion has drawn upon certain highlights of recent federal debt management to show its impact on institutional investors. It is self-evident that the operations of the Treasury and the Federal Reserve have been of great significance to the capital markets in which these investors play the dominant roles. Perhaps the 
true significance of these developments is not yet apparent; yet a few implications seem sufficiently clear to warrant at least tentative appraisal.

A. Investing Institutions Emerge as Dominant Factors in the Capital Markets

During the years following World War II, institutional investors became the dominant factors in the capital markets, particularly in the financing of corporate operations and construction through evidences of debt. As previously mentioned, this is only partly because of the large current flow of funds available for investments. In addition, very large holdings of Government securities made possible much more extensive shifts in the disposition of funds.

As a consequence, it is universally recognized that credit policies and the use of debt management's contribution to economic stability must always include the investing institutions. The commercial banking system is no longer the sole field of such activities. This was officially confirmed when the life insurance companies and mutual savings banks were included in the Voluntary Credit Restraint Program. This is a unique and promising approach to influencing the great multitude of decisions which really make uniform and effective the application of restraint in lending and investing activities. It is inevitable that the investing institutions should thus become active participants, not remote observers, in the arena of monetary and credit policy.

With this growth in importance and prestige comes the usual increase in public responsibility. Investing institutions have realized and must continue to respect their obligation to consider the possible consequences of their actions for the economy as a whole. The promptness with which these responsibilities have been assumed is an effective answer to those who suggest that there should be more extensive regulation of savings institutions.

\section{B. The Challenge to Debt Management}

Similarly, the existing instruments of monetary policy, the Treasury and the Federal Reserve System, have enlarged responsibilities. In addition to the careful consideration which they must give to the effects of their operations on the commercial banking system, they must weigh the impact of alternative courses of action on institutional investors more thoughtfully than ever before. From time to time, conflicting objectives are likely to make the task especially difficult. New techniques must be developed and old shibboleths discarded.

Some of the most promising measures may well prove to be in the area of persuasion to voluntary action, reinforced by moderate action affecting bank reserves on the one hand and the market for long-term bonds on the other. With the great growth in information about economic conditions, it should not be difficult to enlist the support of the responsible lending and investing institutions for efforts to avoid excesses in their operations.

Perhaps the greatest danger lies in the possibility that we shall place too much confidence in our ability to achieve economic stability and become too ambitious in 
our undertakings. Recent as well as more remote experience should make us humble in appraising our ability to forecast future trends, and it should suggest moderation in the exercise of broad powers to influence the decisions of borrowers and lenders. Also, it is tempting to overrate the importance and effectiveness of debt management simply because it looks more feasible to deal with investing institutions and a regulated banking system than it was to deal with millions of individual savers. The tendency is to be too anxious, too prone to be tinkering all the time. This leads to rigidity when we need flexibility, to tight channeling of capital when we need freedom of movement, and to confusion when we need confidence.

The important function of debt management is not in the day-to-day operation of the capital markets, which adjust rather easily and quickly when not hemmed in by excessive controls, but rather in meeting the more critical situations which may occur once or twice in a decade. Even in these periods, however, the limited function and effectiveness of debt management should be recognized. Invariably there are many instruments of economic policy which are of considerably greater importance. Consistency with steps taken in other directions, therefore, is perhaps the true objective.

\section{Marketable vs. Nonmarketable Securities}

Perhaps a useful way to summarize and conclude a discussion of this kind is to state a single proposition as a means of pulling together many variations on a single theme. In this case, the proposition which seems to be supported on theoretical grounds as well as by recent experience is that the Treasury, in its financing through the principal savings institutions, should rely primarily upon marketable bonds which become eligible for commercial bank investment no sooner than two or three years prior to the first call date.

This is an especially important question for institutional investors because the answer may well determine the difficulty or the ease with which they will be able to make major shifts in their portfolios to meet changing conditions over a period of years. The issues are sufficiently fundamental to justify very careful study. No temporary yield advantage or promise of freedom from market fluctuations, therefore, should be allowed to dictate the answer given by institutional investors.

Now that the notion of the sanctity of par has been effectively-and we may hope permanently-eliminated from our thinking, some degree of flexibility has been restored to the interest rate structure. As a result, there is no longer any reason for efforts to "lock up" bonds in the investing institutions for fear of their complicating a pegging operation at some future date. The record of March and April r95I shows that the volume of securities which was "locked up" was that which porffolio managers had no intention of selling. It certainly is very doubtful that any fewer long-term bonds were offered for sale at that time because the Treasury had placed some nonmarketable issues with the savings institutions in previous years.

The fixed redemption schedule designed for Series $F$ and $G$ and Investment Series 
A bonds was related to the prevailing $2 \frac{1}{2}$ per cent long-term rate. It was worked out very carefully to penalize holders who redeemed their bonds prior to maturity and reinvested in a market related to this basic rate. Even the moderate change in the rate structure which followed the removal of the pegs threw the redemption schedule out of gear. When long-term Governments began to yield 2.65 per cent and more to maturity, a significant portion of the outstanding Series $G$ bonds could have been advantageously redeemed. Thus, even though flexibility in the long-term interest rate is likely to be of limited proportions, the case for a predetermined schedule is dealt a devastating blow once fixed price supports have been abandoned.

From the point of view of the Treasury, substantial redemptions of nonmarketable bonds can be a more serious problem than the heavy selling of marketable issues, particularly when the Treasury has a substantial deficit. An orderly decline in bond prices will discourage sales of marketable issues but may stimulate redemptions. It is fallacious to assume that the expansion of bank reserves which accompanies support buying presents a more serious problem than refunding an unpredictable amount of nonmarketable bonds. On the contrary, it may well prove easier to offset open-market buying of long-term bonds at declining prices with sales of short-term bank eligible securities than to prepare the market for new offerings to pay for redemptions.

The purpose of deferring eligibility until the approach of the first call date would be to limit market influences primarily to supply and demand conditions in the long-term capital markets. It is not possible, of course, to isolate the market in restricted bonds from the influences affecting the commercial banks. However, on many occasions the trends may be divergent, especially as to timing. Ineligibility would also serve to encourage institutional investors to hold long-term bonds after they have become medium-term and short-term through the passage of time. Most long-term bonds should probably remain permanently ineligible, but it would be reasonable to permit the Secretary of the Treasury, with the concurrence of the Open Market Committee of the Federal Reserve System, to designate any issue as eligible for commercial bank investment provided it had only two or three years to run to the first call date. This option would give the Secretary an opportunity to facilitate the refunding operation, when appropriate, by enlarging the market. Another means of improving the market for ineligible bonds would be to modify the restrictions on commercial banks acting as dealers.

The question of eligibility is less significant, however, than the basic choice between marketable and nonmarketable securities. The selection of the former will mean that Government securities will continue to perform their highly desirable and essential function of imparting a degree of flexibility and liquidity to the portfolios of investing institutions. It will mean that these investors will continue to be able to shift their investing activities in response to the demands of a dynamic, growing economy. 